\section{Native Woody Plants of the Southern United States with Weedy or Invasive Tendencies: A Review of Common Offenders}

\author{
Michael A. Schnelle ${ }^{1}$
}

ADDITIONAL INDEX WORDs. anthropogenic disturbance, indigenous plants, naturalized, nursery crops

\begin{abstract}
Summary. Five woody species, black locust (Robinia pseudoacacia), yaupon holly (Ilex vomitoria), black cherry (Prunus serotina), snailvine [Cocculus carolinus (formerly Menispermum carolinum or Epibaterium carolinum)], and southern waxmyrtle [Morella cerifera (formerly Myrica cerifera)], are all native to Oklahoma and nearby states. They all have varying levels of use in and importance to the United States nursery industry. Past natural habitats and where these plants have spread to date, either intentionally or naturally, are discussed here. These native plants have migrated to or have become increasingly dominant in regions of the continental United States because of prolific fruit loads dispersed by birds and mammals, anthropogenic disturbances, overgrazing pastures, and certain species' tolerance of environmental extremes. Potential control measures include chemical applications, timely cultivation, heightened awareness of grazing practices, and prescribed burning.
\end{abstract}

$\mathrm{I}$ $n$ most settings, native germplasm proves, in the worst-case scenario, to be "weedy" and, occasionally, invasive. A weed is normally defined as a plant, native or non-native, that is not valued where it is growing (U.S. Department of Agriculture, 2018). In the context of this review, an "invasive" species is defined as a species that not only spreads geographically outside its typical range but also has a proclivity for displacing native flora and fauna. Reichard and White (2001) defined an invasive species as one that has spread or is likely to spread into native flora and managed plant systems, develop self-sustaining populations, and become disruptive and/or dominant in such systems. The definitions of native status and alien status are not

Received for publication 27 Feb. 2019. Accepted for publication 12 Apr. 2019.

Published online 7 August 2019

${ }^{1}$ Department of Horticulture and Landscape Architecture, Oklahoma State University, 358 Agriculture Hall, Stillwater, OK 74078

This paper was part of the Invasive Plants Research Professional Interest Group workshops "Strategies for Mitigating Invasiveness of Native Species," held on 30 Sept. 2017, in Waikoloa, HI, and "It's Native. Wait! It's Exotic...Oh No, It's a Nuisance!" held on 3 Aug. 2018 , in Washington, DC

M.A.S. is the corresponding author. E-mail: mike.schnelle@okstate.edu.

This is an open access article distributed under the CC BY-NC-ND license (https://creativecommons.org/ licenses/by-nc-nd/4.0/).

https://doi.org/10.21273/HORTTECH04334-19 founded on hard science; instead, they reflect a set of value judgements about the timescales of environmental changes and forms of human impact regarded as acceptable within the landscape (Kendle and Rose, 2000). Often when a native species is deemed invasive, the invasion is associated with anthropogenic disturbance (Simberloff et al., 2012). Changes in climatic conditions that have transpired over recent decades have resulted in altered population dynamics of native species and, thus, their geographic ranges (Walther et al., 2009).

It is possible that native plant invasions have been underreported. In fact, they can be significant and independent of local land-use changes, and they can be influenced by the global climate. It is estimated that $10 \%$ to $20 \%$ of all invasive plant species in North America are native to the United States (Nackley et al., 2017). The debate regarding native vs. non-native and weedy vs. invasive is beyond the intended scope of this work, but it has been summarized by Kendle and Rose (2000). The objective of this work was to illuminate species important to the ornamentals industry and end-consumers that, through natural geographical expansion, sheer aggressive growth in native locations, or anthropogenic activity, can sometimes be challenging to keep in-bounds, both in cultivation and in natural ranges. Although not an exhaustive list, a few species that warrant closer monitoring in the southern United States and other regions of the country are presented.

\section{Black locust}

The black locust is a 40 - to $60-\mathrm{ft} \times$ $35-\mathrm{ft}$ tree that is native to forest edges and slopes in the Southern Appalachian and Ozark mountains of the United States (disjunct populations). At one time, this species was reported in 12 states, but it is now found throughout the continental United States. Black locust has displaced other native species in the northeast, mid-Atlantic, and midwest regions of the United States, as well as California (Brusati, 2005; U.S. Department of Agriculture, 2007). It was intentionally introduced outside its range, both in the United States and abroad, because of its ability to mitigate soil erosion and its usefulness for land reclamation from mining. Black locust is now growing throughout most of the United States. The success of this tree outside of its native range is attributable to its high photosynthetic rate, seed dispersal by birds and mammals, fast seed germination, rapid seedling growth, extensive root system, tolerance of low fertility, high genetic variability, and resistance to drought stress, air pollutants, temperature extremes, and most fungal decay (Hanover, 1990; Sabo, 2000). Because black locust quickly shades sun-loving plants, it invades disturbed habitats, degraded woods, and thickets, consequently overwhelming native species of prairies, oak savannas, and upland forests, where it ultimately forms a monoculture (California Invasive Plant Council, 2006; Nix, 2017). Suckering results in dense clones that create

\begin{tabular}{llll}
\hline $\begin{array}{l}\text { Units } \\
\begin{array}{l}\text { To convert U.S. to SI, } \\
\text { multiply by }\end{array}\end{array}$ & U.S. unit & SI unit & $\begin{array}{l}\text { To convert SI to U.S., } \\
\text { multiply by }\end{array}$ \\
\hline 0.3048 & $\mathrm{ft}$ & $\mathrm{m}$ & 3.2808
\end{tabular}


shaded islands with little ground vegetation. The lack of ground fuel can render the use of fire futile in natural disturbance regimes (Wieseler, 2009). Control measures have included bulldozing and scraping the soil surface, prescribed burns, and annual haying, which may prove viable for eradicating vulnerable first-year seedlings. Others have combined mechanical control with herbicides. When black locust is near desirable vegetation, phytotoxicity can occur as a result of aerial applications or runoff injury with herbicides such as triclopyr. Glyphosate has also been used with varying success. Prescribed burning, cutting, or pulling plants often result in increased suckering and vigorous re-sprouting (Missouri Department of Conservation, 2013). Biological control has been contemplated and/or attempted (Sabo, 2000); however, to date, there is no USDA-approved biocontrol agent (DiTomaso and Kyser, 2013; Wieseler, 2009). Although many cultivars and selections exist for this species, Lace Lady and Frisia seed heavily, with the exception of Pyramidalis, Purple Robe, and possibly others that are less reproductive. Even if sterility were achieved, and if the resulting selections were aggressively marketed, such plants would still likely sucker, be resistant to herbicides, and thrive in a number of environmental extremes. Although the species is ornamental and has value for erosion control, land reclamation, and other uses, it should be sold and planted with forethought. Massachusetts and Minnesota, respectively, have ordered sales bans and deemed it noxious (Minnesota Department of Natural Resources, 2019).

\section{Yaupon holly}

Yaupon holly is a small tree to large shrub that can grow from 20 to $30 \mathrm{ft}$ in height and 10 to $15 \mathrm{ft}$ in width. This species is a highly soughtafter native woody ornamental due to its ease of culture and showy characteristics, particularly its glossy foliage and showy red berries on female plants. The native range of yaupon holly is from Virginia to Florida and from Oklahoma to Texas along the coastal plains and maritime forests (southeastern United States). However, despite its indigenous status, it has proven to be weedy, if not invasive, under certain conditions and within defined geographic boundaries (Linex, 2014). Although native to the North Carolina Coastal Plain, it has escaped to the Sandhills and Piedmont regions (North Carolina Native Plant Society, 2017). East Texas landowners perceive this plant to be an invasive species (Vorderbruggen, 2008). Dense, monotypic stands in forest understories have inhibited indigenous herbaceous shrub and tree regeneration. This, in turn, has led to less biodiversity and enhanced fuel loads (Oswald et al., 2017). Limitations such as salt intolerance (Paudel and Battaglia, 2015) will likely halt any further encroachment, particularly as it pertains to coastal regions, although the species does inhabit these areas in limited populations.

Researchers found that prescribed burning reduced the canopy of yaupon holly but failed to cause mortality. However, when diesel or diesel combined with triclopyr herbicide was applied 6 and 18 months after burning, a mortality rate as high as $92 \%$ was achieved (Mitchell et al., 2005 ). Yaupon holly is dioecious with some of the dwarf selections, such as 'Nana' and 'Bordeaux', that are essentially sterile/fruitless. Selecting male cultivars to mitigate weediness would likely be futile because of the widespread populations of the species, and it would be counterproductive because of the highly soughtafter showy fruits borne from female plants, which are its greatest selling point.

\section{Black cherry}

Black cherry is native to the eastern United States (Coastal Plains Plants Wiki, 2007), but it can be found as far west as Oklahoma and Texas in canyons, valleys, and rich bottomlands. It is an attractive 50$\mathrm{ft}$-tall $\times 30$-ft-wide tree with glossy foliage, showy white fragrant spring flowers, and beautiful but messy red/ blue drupes in copious amounts in late summer to fall. Its fall color can be striking, with hues of yellow, orange, red, and purple. With its hard, reddish-brown wood, black cherry is commercially significant in the furniture industry, and it is used for paneling, handles, and toys (National Museum of American Illustration, 2018). Additionally, it has been useful for reclamation of surface mine spoil. Black cherry is primarily carried by specialty growers and/or those specifically touting natives of the United States. It is sometimes regarded as weedy to marginally invasive in the United States, and it is became decisively invasive in Europe soon after its introduction. It has been introduced or spread to other states, with Minnesota deeming it noxious and prohibiting its sale (Invasive Plant Atlas of the United States, 2018a; Uva et al., 1997). Black cherry can grow in a number of environmental extremes, with the exception of chronically wet soils. Given the heavy fruit load annually dispersed by birds and mammals, it has naturally spread and/or has been intentionally introduced throughout the United States, well beyond its aforementioned native range. Naturally occurring botanical varieties exist within the United States, but all share a propensity toward heavy fruit set, thus contributing to weediness in their native range or encroachment in areas not originally in the species' native habitat.

\section{Snailvine}

Native to the midwestern and southeastern United States, snailvine is valued for its shiny, green, heartshaped deciduous to semi-evergreen foliage, brilliant red fruits, and ability to quickly cover unsightly areas or trellises in landscape settings. This vine grows from 6 to $12 \mathrm{ft}$ in length, and it is commercially available; however, it is normally offered by specialty growers as a niche or novelty ornamental due to its reputation for rampant growth and its status of being challenging to "tame" (Stump, 2013; Vogelpohl, 2014). Snailvine often dominates the "landscape" in both its native range and beyond due to its highly reproductive nature via seeds and root sprouts, even with attempts to eradicate this species (Smith-Rodgers, 2009). This aggressive colonizer (Native Plant Information Network, 2008) is very drought-tolerant and can tolerate a broad spectrum of light exposure, making it competitive, if not dominant (Rector, 2013). Although mechanical control measures work, they are often temporary due to sprouting from roots and stubs. Chemical control, although often tenuous due to the sheer tenacity of this native species, 
has been accomplished via glyphosate (with repeat applications necessary). Because snailvine often grows over desirable vegetation, it is challenging to kill unwanted vegetation without causing phytotoxicity to desirable species in the vicinity (National Plant Information Network, 2008). The selection of male cultivars would be counterproductive because the red fruits are the main impetus for growing this native vine. Rather, careful siting and monitoring of this species would be prudent.

\section{Southern waxmyrtle}

Southern waxmyrtle is a small tree to large shrub up to $25 \times 15 \mathrm{ft}$ (Gilman and Watson, 2014) that is valued for its evergreen foliage, showy blue fruits, and overall pleasing growth habit. The original range for southern waxmyrtle was the southeastern United States from New Jersey to Florida and westward to Texas (Williamson, 2015); however, the species is now colonizing other areas of the country or behaving aggressively in its native range and is sometimes deemed invasive (Coder, 2016; Invasive Plant Atlas of the United States, 2018b). The species is opportunistic and will quickly dominate disturbed areas such as clear cuts and oil fields (Keener et al., 2019). Shiflett et al. (2017) described southern waxmyrtle's ability to efficiently capture light and utilize internal water movement. These factors promote rapid thicket formation while simultaneously discouraging colonization and expansion of co-occurring species. Furthermore, this dense growth poses a fire hazard. Paudel and Battaglia (2015) hypothesized that southern waxmyrtle had restricted distributions near coastal areas, largely due to tidal flooding and higher salinity. However, it can still be found in eastern coastal areas and is somewhat tolerant of salt spray (North Carolina State Extension, 2018). Southern waxmyrtle is adapted to full sun to shade, is $\mathrm{pH}$ insensitive, tolerates wet to dry and even saline soils, and fixes nitrogen. Because it can thrive in poor soils, it is highly adaptable and outcompetes other plant materials within or outside its native range in the United States. No cultivars to date have proven to be useful alternatives for reducing its propensity to spread and grow aggressively under certain conditions. Up to $70 \%$ of southern waxmyrtle has been controlled with triclopyrpicloram mixtures (Shiver et al., 1991). Various tests of burning, chopping, and blading methods for this species indicated that it can reestablish itself to pretreatment levels within 3 years (Van Deelen, 1991).

\section{Summary and conclusions}

Because of the exponential increase in atmospheric carbon dioxide $\left(\mathrm{CO}_{2}\right)$ concentrations and the resulting impacts on climate, it is more likely that both endemic and alien plants will drastically alter ranges, resulting in the expansion of species in some situations but diminished ranges and populations in other scenarios (Nackley et al., 2017). Many invasive events are a result of anthropogenic disturbance; therefore, the onus is on scientists, growers, and consumers to keep a watchful eye on land stewardship and other factors that could influence a species' performance relative to other plants in the same biological community. The native species, like introduced plant materials, should be judged on a case-by-case basis. Marble (2018) suggested that plant selection for a landscape should be predicated on environmental benefits, aesthetic value, and long-term maintenance needs/issues, including the potential for unwanted spread regardless of the origin of the species.

Few native species are aggressive enough to warrant production and sales bans in the southern United States; however, they should be monitored. Regarding potentially problematic native species, Davis et al. (2011) remarked that conservationists and land managers should organize priorities based on whether species are producing benefits or harm to biodiversity, human health, ecological services, and economies. Control measures should range from total eradication to toleration of the "new" species as enriching local biodiversity and facilitating ecosystem restoration as native communities re-assemble and go forward under a new climate regime (Walther et al., 2009). Most genera are opportunistic, and it is noteworthy to observe that native invasions are not unique to the United States; they occur worldwide (Nackley et al., 2017). Current management approaches must acknowledge that natural systems of the past are changing forever due to climate change, nitrogen eutrophication, increased urbanization, and other changes in land use (Davis et al., 2011).

\section{Literature cited}

Brusati, E. 2005. Robinia psendoacacia. 4 Jan. 2019. <https://www.cal-ipc.org/ plants/paf/robinia-pseudoacacia-plantassessment-form $/>$.

California Invasive Plant Council. 2006. California invasive plant inventory. CalIPC Publ. 2006-02. California Invasive Plant Council, Berkeley, CA.

Coastal Plains Plants Wiki. 2007. Prunus serotina. 16 Dec. 2018 . <http:// coastalplainplants.org/wiki/index.php/ Prunus_serotina>.

Coder, K.D. 2016. Invasive trees of Georgia. Univ. Georgia Publ. No. 39.

Davis, M., M.K. Chew, R.J. Hobbs, A.E. Lugo, J.J. Ewel, G.J. Vermeij, J.H. Brown, M.L. Rosenzweig, M.R. Gardener, S.P. Carroll, K. Thompson, S.T.A. Pickett, J.C. Stromberg, P.D. Tredici, K.N. Suding, J.G. Ehrenfeld, J.P. Grime, J. Mascaro, and J.C. Briggs. 2011. Don't judge species on their origins. Nature 474(7350):153-154.

DiTomaso, J.M. and G.B. Kyser. 2013. Weed control in natural areas in the western United States. Weed Res. Info. Ctr., Univ. California, Davis.

Gilman, E.F. and D.G. Watson. 2014. Myrica cerifera: Southern waxmyrtle. Univ. Florida, Inst. Food Agr. Sci., IFAS Publ. ENH-569.

Hanover, J.W. 1990. Physiological genetics of black locust (Robinia psenodoacacia L.): A model multipurpose tree species, p. 175-183. Proc. Conf. on Fast Growing and Nitrogen Fixing Trees, Univ. Marburg, West. Germany, 8-12 Oct. 1989.

Invasive Plant Atlas of the United States. 2018a. Black cherry. 14 Jan. 2019. <https://www.invasiveplantatlas.org/ subject.html?sub $=2796>$

Invasive Plant Atlas of the United States. 2018b. Southern waxmyrtle. 14 Jan. 2019. <https://www.invasiveplantatlas.org/ subject.html? sub $=605 \mathrm{l}>$.

Keener, B.R., A.R. Diamond, L.J. Davenport, P.G. Davison, S.L. Ginzbarg, C.J. Hansen, C.S. Major, D.D. Spaulding, J.K. Triplett, and M. Woods. 2019. Alabama plant atlas: Morella cerifera. 24 Feb. 2019. <http://atlas.uwa. edu/Plant.aspx?id $=2685>$.

Kendle, A.D. and J.E. Rose. 2000. The aliens have landed! What are the justifications for 'native only' policies in landscape 
plantings? Landsc. Urban Plan. 47(1):1931 .

Linex, R. 2014. Can a native plant be noxious or invasive? 6 July 2018. <https://npsot.org/wp/story/2014/ $6872 />$.

Marble, S.C. 2018. Native weedy pests of the Deep South. HortScience 53:12441249.

Minnesota Department of Natural Resources. 2019. Black locust (Robinia pseudoacacia). 25 Jan. 2019. <https://www. dnr.state.mn.us/invasives/terestrialplants/ woody/blacklocust.html>.

Missouri Department of Conservation. 2013. Black locust control. 5 Jan. 2019. <https://mdc.mo.gov/trees-plants/ problem-plant-control/nuisance-nativeplants/black-locust-control/>.

Mitchell, R.B., J.C. Cathey, B. Dabbert, R. Sosebee, and D.F. Prochaska. 2005. Managing yaupon with fire and herbicides in the Texas post oak savannah. USDAARS/UNL Faculty 201.

Nackley, L.L., A.G. West, A.L. Skowno, and W.J. Bond. 2017. The nebulous ecology of native invasions. Trends Ecol. Evol. 32(11):814-824.

National Museum of American Illustration. 2018. Black cherry (Prunus serotina). 10 July 2018. <https://americanillustration. org/project/prunus-serotina/>.

Native Plant Information Network. 2008. Cocculus carolinus. 3 Dec. 2018. <https:// www.wildflower.org/plants/result.php?id_ plant $=$ COCA $>$.

Nix, S. 2017. Seven common invasive tree species in North America. 12 Nov. 2018. <https://www.thoughtco.com/sevencommon-invasive-tree-species-in-northamerica-4108964>.

North Carolina Native Plant Society. 2017. Ilex vomitoria. 1 Nov. 2018. <https: www.ncwildflowers.org/plant_galleries / details/ilex-vomitoria/ $>$.

North Carolina State Extension. 2018. Myrica cerifera. 5 Jan. 2019. <https:// plants.ces.ncsu.edu/plants/all/myricacerifera $/>$.
Oswald, B.P., M.J. Beierle, K.W. Farrish, H.M. Williams, and I. Hung. 2017. Biomass estimations of invasives yaupon, chinese privet and chinese tallow in east Texas hardwood and pine ecosystems. For. Res. 6(2):1-9.

Paudel, S. and L.L. Battaglia. 2015. The role of light, soil and human factors on the probability of occurrence of an invasive and three native plant species in coastal transitions of coastal Mississippi, USA. J. Plant Ecol. 8(5):491-500.

Rector, B.S. 2013. Invasive vine. 9 Jan. 2019. <https://ask.extension.org/ questions/127077>.

Reichard, S.H. and P. White. 2001. Horticulture as a pathway of invasive plant introductions in the United States. Bioscience $51(2): 103-113$.

Sabo, A.E. 2000. Robinia pseudoacacia invasions and control in North America and Europe. Student On-line J. 6(3):1-9.

Shiflett, S.A., J.C. Zinnert, and D.R Young. 2017. Functional traits of expanding thicket-forming shrubs: Contrasting strategies between exotic and native species. Ecosphere 8(9):1-15 (article e01918).

Shiver, B.D., S.A. Knowe, M.B. Edwards, and W.N. Kline. 1991. Comparison of herbicide treatments for controlling common coastal plain flatwoods species. South. J. Appl. For. 15(4):187-193.

Simberloff, D., L. Souza, M.A. Nunez, M.N. Barrios-Garcia, and W. Bunn. 2012. The natives are restless, but not often and mostly when disturbed. Ecology 93(3):598607.

Smith-Rodgers, S. 2009. Window on a Texas wildscape: Obnoxious vines. 9 Jan. 2019. <http://sherylsmithrodgers. blogspot.com /2009/05/obnoxiousvines.html>

Stump, B. 2013. Living lightly in Williamson County: Driven to distraction by an invasive weed. 9 Jan. 2019. <http:// livinglightlyinwilliamsoncounty.blogspot. com $/ 2013 / 05 /$ driven-to-distraction-byinvasive-weed.html/>.
U.S. Department of Agriculture. 2007. Release brochure for Steiner Group black locust (Robinia pseudoacacia). U.S. Dept. Agr., Natural Resources Conservation Serv., Norman A. Berg Natl. Plant Materials Ctr., Beltsville, MD.

U.S. Department of Agriculture. 2018. National Invasive Species Information Center (NISIC). 11 Nov. 2018. <https:// www.invasivespeciesinfo.gov/index. shtml/>.

Uva, R.H., J.C. Neal, and J.M. DiTomaso. 1997. Weeds of the Northeast. Cornell Univ. Press, Ithaca, NY.

Van Deelen, T.R. 1991. Fire effects information system: Morella cerifera. 25 Nov. 2018. <https://www.fs.fed.us/ database/feis/plants/shrub/morcer/all. html\#FIRE\%20EFFECTS>.

Vogelpohl, S. 2014. Know your natives Carolina moonseed. 13 Dec. 2018. <https://anps.org/2014/11/23/knowyour-natives-carolina-moonseed $/>$.

Vorderbruggen, M. 2008. Foraging Texas. 6 July 2018. <http://www. foragingtexas.com $/ 2008 / 08 /$ yauponholly.html>.

Walther, G.-R., A. Roques, P.E. Hulmes, M.T. Sykes, P. Pysek, I. Kuhn, M. Zobel, S. Bacher, Z. Botta-Dukat, H. Bugmann, B. Czucz, J. Dauber, T. Hickler, V. Jarosik, M. Kenis, S. Klotz, D. Minchin, M. Moora, W. Nentwig, J. Ott, V.E. Panov, B. Reineking, C. Robinet, V. Semenchenko, W. Solarz, W. Thuiller, M. Vila, K. Vohland, and J. Settele. 2009. Alien species in a warmer world: Risks and opportunities. Trends Ecol. Evol. 24(12):686-693.

Wieseler, S. 2009. Black locust. 15 Jan. 2019. <https://www.invasive.org/ alien/fact/ropsl.html>.

Williamson, J. 2015. Waxmyrtle. Clemson coop. ext. factsheet HGIC 1076. 11 Jan. 2019. <https:/hgic.clemson.edu/ factsheet/waxmyrtle/ $>$. 